P-ISSN: 2615-1723

E-ISSN: 2615-1766

April 2018
Jurnal Riset Pendidikan Dasar

1 (1), (2018) $72-77$

Submitted: Februari, Accepted: Maret, Published: April

\title{
STUDI KOMPARASI STRATEGI PEMBELAJARAN CARTOON CARD DENGAN COURSE REVIEW HORAY TERHADAP MOTIVASI BELAJAR MATEMATIKA PADA SISWA KELAS III
}

\author{
Dina Puspitasari \\ Program Studi Pendidikan Guru Sekolah Dasar, Fakultas Keguruan dan Ilmu Pendidikan, Universitas \\ Muhammadiyah Surakarta, Indonesia
}

Korespondensi.E-mail: dinna.puzz1@gmail.com

\begin{abstract}
Abstrak
Penelitian ini bertujuan untuk mengetahui: 1) perbedaan motivasi belajar Matematika antara penerapan strategi pembelajaranCartoon Card dengan Course Review Horay pada siswa, 2) strategi mana yang lebih besar pengaruhnya terhadap motivasi belajar Matematika antara strategi pembelajaran Cartoon Card dengan Course Review Horay pada siswa. Penelitian ini merupakan penelitian eksperimen kuantitatif. Populasi dalam penelitian ini adalah seluruh siswa SD Negeri Kleco 1 No.7 Surakarta. Teknik sampling yang digunakan adalah purposive sampling. Sampel yang diambil adalah siswa kelas III.1 dan III.2. Teknik pengumpulan data yang digunakan adalah angket dan dokumentasi. Teknik analisis data yang digunakan adalah uji t yang sebelumnya dilakukan analisis prasyarat menggunakan uji normalitas. Hasil analisis data dengan taraf signifikansi 5\% diperoleh: 1) tidak terdapatperbedaan motivasi belajar Matematika antara penerapan strategi pembelajaranCartoon Card dengan Course Review Horay pada siswa kelas 3 SD Negeri Kleco 1 No.7 Surakarta yang dibuktikan dengan thitung $<$ $\mathrm{t}_{\text {tabel, }}$ yaitu $0,78<2,301$ dan nilai probabilitas $\left.0,938>0,05,2\right)$ strategi pembelajaran Cartoon Cardsetarapengaruhnya dengan Course Review Horay terhadap motivasi belajar Matematikapada siswa kelas 3 SD Negeri Kleco 1 No.7 Surakarta dan dibuktikan dengan skor rata-rata motivasi belajar Matematika kelas 3.1yang tidak berbeda secara signifikan dengan kelas 3.2, yaitu adalah $91,80-91,60=0,20$.
\end{abstract}

Kata Kunci: Cartoon Card, Course Review Horay, motivasi belajar Matematika

\section{COMPARATIVE STUDY OF CARTOON CARD LEARNING STRATEGY WITH COURSE REVIEW HORAY ON MATH MAINTENANCE LEARNING MOTIVATION IN CLASS III STUDENTS}

\begin{abstract}
This study aims to determine: 1) the difference of learning motivation Mathematics between the implementation of learning strategy Cartoon Card with Course Review Horay on students, 2) Which strategy is greater influence on learning motivation Mathematics between learning strategy Cartoon Card with Course Review Horay on students. This research is a quantitative experimental research. The population in this study were all students of SD Negeri Kleco 1 No.7 Surakarta. The sampling technique used is purposive sampling. Samples taken are students of class III.1 and III.2. Data collection
\end{abstract}

Copyright @2018, JRPD, ISSN 2615 - 1723 (Print), ISSN 2615 - 1766 (Online) 


\section{Jurnal Riset Pendidikan Dasar, 1 (1), April 2018 (72-77) \\ Dina Puspitasari}

techniques used are questionnaires and documentation. Data analysis technique used is test which previously conducted prerequisite analysis using normality test. Result of data analysis with $5 \%$ significance level obtained: 1) there is no difference of learning motivation Mathematics between applying of learning strategy Cartoon Card with Course Review Horay at grade 3 student of SD Kleco 1 No.7 Surakarta which proved by $\mathrm{t}$ count $<$ ttabel, that is $0,78<2,301$ and probability value $0,938>0,05,2)$ Cartoon Cards teaching strategy shears with Course Review Horay to motivation learn Mathematics in grade 3 of SD Kleco 1 No.7 Surakarta and proved by average score of motivation learn Mathematics class 3.1 which is not different significantly with class 3.2 , ie is $91.80-91.60=0.20$.

Keywords: Cartoon Card, Course Review Horay, motivation to learn math

\section{PENDAHULUAN}

Pada dasarnya pendidikan adalah laksana eksperimen yang tidak pernah selesai sampai kapan pun, sepanjang ada kehidupan manusia di dunia ini. Proses pendidikan seumur hidup itu lebih dikenal dengan istilah long life education. Beragam program inovatif ikut serta memeriahkan reformasi pendidikan, misalnya dalam memperbaiki pola hubungan sekolah dengan lingkungannya dan dengan pemerintah, bahkan upaya perbaikan dalam kualitas pembelajaran yang dilakukan (Hasbullah, 2009: $1-8)$.

Salah satu komponen penting yang dapat menentukan kualitas pendidikan adalah guru, karena peran mereka sangat sentral terutama sebagai pemegang kendali dalam proses pembelajaran. Untuk mengoptimalkan peran guru tersebut, peningkatan kualitas guru itu sendiri menjadi sebuah keharusan. Diantara tanda-tanda guru yang berkualitas, apabila dapat menunjukkan kemampuan pengelolaan pembelajaran yang bermutu (Surtikanti dan Joko Santoso, 2008: 2). Dalam Undang-Undang Sistem Pendidikan Nasional Nomor 20 tahun 2003 pasal 40 ayat 2 dinyatakan bahwa "Pendidik dan tenaga kependidikan berkewajiban menciptakan suasana pendidikan yang bermakna, menyenangkan, kreatif, dinamis dan dialogis".Namun, pada kenyataannya tidak sedikit guru yang mengalami kurang berhasilnya pembelajaran yang dilakukan, sehingga menuntutnya untuk selalu berfikir dan berusaha menyajikan pembelajaran yang menarik dan menyenangkan disemua mata pelajaran.
Salah satu mata pelajaran yang dirasa sulit dalam penyampaiannya pada siswa yaitu mata pelajaran Matematika. Selama ini terbentuk kesan umum pada siswa bahwa Matematika merupakan mata pelajaran yang sulit dan juga menakutkan (Heruman, 2007: 1-3). Matematika selalu berhubungan dengan angka-angka yang terkesan membingungkan dan membosankan, yang berdampak pada rendahnya motivasi belajar siswa.

Ditinjau dari usia siswa sekolah dasar (SD), usianya berkisar antara $6-13$ tahun dan biasa disebut golden age.Sebagian besar anak pada usia ini menyukai tokoh-tokoh fiksi yang terdapat pada acara televisi.Hal tersebutterlihat pada gambar kartun dalam tas dan alat tulis yang dibawa. Siswa usia sekolah dasar juga mulai mampu berkompetisi dengan teman sebaya(Saring, dkk, 2008: 48-54). Karakteristik anak usia demikian dalam pembelajaran di kelas selalu menginginkan suasana belajar yang asyik, menarik, menyenangkan, dan terdapat unsur permainan. Oleh karena itu, strategi Cartoon Card dan Course Review Horay dirasa cocok untuk diterapkan dalam pembelajaran Matematika.

Faisal, dkk. (2013: 1) menjelaskan bahwa strategi CartoonCard dalam istilah lainnya (dalam Bahasa Idonesia) disebut juga dengan 'kartu kartun'. Strategi Cartoon Cardadalah strategi pembelajaran yang menggunakan media kartu yang berupa gambar kartun untuk mengeksplor atau menuliskan bagian materi mana yang belum dipahami siswa.

Strategi Course Review Horay, menurut Echlos dalam Galuh (2012: 9), dalam Bahasa Inggris Course berarti jalan atau rangkaian 
pelajaran.Review berarti tinjauan/pemeriksaan. SedangkanHoray adalah yel-yel berupa teriakan horay atau semacamnya.Strategi Course Review Horaymerupakanrangkaian pembelajaran dengan penguji pemahaman siswa dengan menggunakan soal dimana jawaban soal dituliskan pada kartu atau kotak yang telah dilengkapi nomer dan untuk siswa atau kelompok yang mendapatkan jawaban benar harus berteriak horay atau menyanyikan yel-yel kelompoknya (Galuh, 2012: 9).

Penelitian ini bertujuan untuk mengetahui perbedaan motivasi belajar Matematika antara pembelajaran dengan strategi Cartoon Card dan Course Review Horay pada siswa kelas 3 SD Negeri Kleco 1 No. 7 Surakarta tahun pelajaran 2013/2014. Selanjutnya, dapat diketahui strategi mana yang lebih besar pengaruhnya terhadap motivasi belajar Matematika antara kedua strategi tersebut.

Berdasarkan uraian di atas maka dilakukan penelitian dengan judul "Studi Komparasi Strategi Pembelajaran Cartoon Card dengan Course Review Horay Terhadap Motivasi Belajar Matematika pada Siswa Kelas 3 SD Negeri Kleco 1 No.7 Surakarta”.

\section{METODE}

Jenis penelitian ini adalah penelitian eksperimen kuantitatif. Penelitian ini dilaksanakan di kelas 3 SD Negeri Kleco 1 No. 7 Surakarta yang beralamat di Jalan Brigjend Slamet Riyadi No. 554 Surakarta. Populasi dalam penelitian ini adalah seluruh siswa SD Negeri Kleco 1 No.7 Surakarta. Teknik sampling yang digunakan purposive sampling. Berdasarkan teknik purposive sampling, sampel yang digunakan adalah siswa kelas 3.1 dan 3.2 SD Negeri Kleco 1 No.7 Surakarta tahun pelajaran 2013/2014.

Ada dua variabel dalam penelitian ini, yaitu variabel independen(bebas) dan variabel dependen (terikat). Variabel bebas dalam penelitian ini adalah strategi pembelajaran Cartoon Card dan Course
Review Horay.Sedangkan variabel terikatnya adalah motivasi beajar Matematika.

Teknik pengumpulan data yang digunakan adalah angket dan dokumentasi. Penelitian ini bertujuan untuk mengetahui perbedaan motivasi siswa dalam belajar Matematika. Untuk itu, setelah dilakukan perlakuan penerapan strategi pembelajaran Cartoon Card dan Course Review Horay,siswa diberikan angket untuk mengukur motivasi siswa dalam belajar Matematika.Angket motivasi belajar Matematika yang diberikan kepada siswadisajikan dalam bentuk skala Likert dengan interval skor 1-4. Sebelum diberikan pada kelas eksperimen, instrumen angket terlebih dahulu dilakukan uji validitas dan uji reliabilitas melalui try out (uji coba). Uji tersebut dilakukan untuk mendapatkan instrumen yang baik. Sedangkan dokumentasi yang digunakan dalam penelitian ini adalah untuk memperoleh datadata seperti profil sekolah, identitas siswa, foto, serta data pendukung lainnya.

Teknik analisis data yang digunakan untuk menguji hipotesis yang diajukan adalah uji t. Sebelum dilakukan uji hipotesis menggunakan rumus t-tes, dilakukan uji prasyarat analisis. Uji prasyarat analisis yang dilakukan adalah uji normalitas dengan metode Liliefors.

\section{HASIL DAN PEMBAHASAN}

Instrumen yang valid dan reliabel sejumlah 28 butir item pernyataan digunakan untuk memperoleh data motivasi belajar Matematika pada siswa dalam masingmasing kelas eksperimen. Kelas eksperimen 1 (3.1) diberi perlakuan dengan strategi pembelajaran Cartoon Card, diperoleh skor motivasi belajar Matematika tertinggi 110 dan terendah 69. Dari keseluruhan skor yang diperoleh siswa kelas 3.1 dapat ditentukan rata-rata skor 91,80. Hasil pengelompokkan dengan interval yang dilakukan terhadap data skor motivasi belajar Matematika siswa kelas 3.1 ditunjukkan dalam tabel berikut. 
Jurnal Riset Pendidikan Dasar, 1 (1), April 2018 (72-77)

Dina Puspitasari

Tabel 1 Hasil Pengelompokkan Data Motivasi Belajar Matematika Siswa Kelas 3.1

\begin{tabular}{ccccc}
\hline Interval Skor & $\mathrm{Xi}$ & Frekuensi & $\begin{array}{c}\text { Frekuensi } \\
\text { Kumulatif }\end{array}$ & $\begin{array}{c}\text { Frekuensi } \\
\text { Relatif }(\%)\end{array}$ \\
\hline $69-75$ & 72 & 2 & 2 & 6,7 \\
$76-82$ & 79 & 4 & 6 & 13,3 \\
$83-89$ & 86 & 5 & 11 & 16,7 \\
$90-96$ & 93 & 10 & 21 & 33,3 \\
$97-103$ & 100 & 5 & 26 & 16,7 \\
$104-110$ & 107 & 4 & 30 & 13,3 \\
\hline
\end{tabular}

Kelas eksperimen 2 (3.2) diberi kelas 3.2 dapat ditentukan rata-rata skor perlakuan dengan penerapan strategi pembelajaran Course Review Horay, dari data angket diperolehskor motivasi belajar Matematika tertinggi 111 dan terendah 71. Dari keseluruhan skor yang diperoleh siswa 91,60. Hasil pengelompokkan dengan interval yang dilakukan terhadap data skor motivasi belajar Matematika siswa kelas 3.2 ditunjukkan dalam tabel berikut.

Tabel 2 Hasil Pengelompokkan Data Motivasi Belajar Matematika Siswa Kelas 3.2

\begin{tabular}{ccccc}
\hline Interval Skor & $\mathrm{Xi}$ & Frekuensi & $\begin{array}{c}\text { Frekuensi } \\
\text { Kumulatif }\end{array}$ & $\begin{array}{c}\text { Frekuensi } \\
\text { Relatif (\%) }\end{array}$ \\
\hline $71-77$ & 74 & 3 & 3 & 10 \\
$78-84$ & 81 & 3 & 6 & 10 \\
$85-91$ & 88 & 11 & 17 & 36,7 \\
$92-98$ & 95 & 6 & 23 & 20 \\
$99-105$ & 102 & 2 & 25 & 6,7 \\
$106-112$ & 109 & 5 & 30 & 16,7 \\
\hline
\end{tabular}

Sebelum dilakukan analisis data, terlebih dahulu dilakukan uji prasyarat analisis atau uji normalitas yang diperoleh kesimpulanbahwa data sampel dari masingmasing kelas berdistribusi normal. Selanjutya dilaukan analisis data berupa pengujian hipotesis pertama yang menggunakan uji independent sample t-test.

Berdasarkan pengujian hipotesis di atas, pada baris equal variances assumed diperoleh $t_{\text {hitung }}=0,078$. Pada taraf signifikansi $5 \%$ dan $\mathrm{dk}=58$ diperoleh nilai $\mathrm{t}_{(0,025 ; 58)}=2,301$ yang berarti $t_{\text {hitung }}<t_{\text {tabel }}$ ( $0,078<2,301)$, dan nilai probabilitas $0,938>$ 0,05 . Dengan demikian dapat disimpulkan bahwa $\mathrm{H}_{0}$ diterima. Hal ini menunjukkan bahwa tidak terdapat perbedaan motivasi belajar Matematika antara penerapan strategi pembelajaran Cartoon Card dengan strategi pembelajaran Course Review Horaypada siswa kelas 3 SD Negeri Kleco 1 No.7 Surakarta tahun pelajaran 2013/2014.
Selanjutnya dilakukan pengujian hipotesis kedua untuk mengetahui strategi manakah yang dapat memberikan motivasi belajar Matematika yang lebih baik pada siswa kelas 3 SD Negeri Kleco 1 No. 7 Surakarta tahun pelajaran 2013/2014. Pengujian dilakukan dengan membandingkan skor rata-rata motivasi belajar Matematikadari kedua kelas sebagai berikut.

Skor rata-rata motivasi belajar Matematika siswa yang yang diberi perlakuan strategi pembelajaranCartoon Cardlebih tinggi daripada yang yang diberi perlakuan strategi pembelajaran Course Review Horay karena 91,80>91,60. Selisih skor rata-rata angket motivasi belajar Matematika tidak signifikan yaitu 91,80 $91,60=0,20$. Jadi, keputusan ujinya $\mathrm{H}_{0}$ ditolak danH $_{1}$ diterima. Penelitian ini membuktikan bahwa strategi pebelajaran Cartoon Card tidak lebih besar pengaruhnya atau setara dengan strategi pembelajaran Course Review Horay terhadap motivasi belajar Matematika 
pada siswa kelas 3 SD Negeri Kleco 1 No.7 Surakarta tahun pelajaran 2013/1014.

Berdasarkan hasil analisis data yang dilakukan, diketahui tidak terdapat perbedaan motivasi belajar Matematika antara penerapan strategi pembelajaran Cartoon Card dengan Course Review Horaypada siswa kelas 3 SD Negeri Kleco 1 No.7 Surakarta tahun pelajaran 2013/2014. Hal ini disebabkan masing-masing strategi mempunyai karakteristik yang sama-sama memiliki pegaruh besar terhadap motivasi belajar Matematika siswa. Quantum Teaching memegang asas utama dalam sebuah pembelajaran. Dalam bukunya DePorter Bobbi, dkk (2000:6) menyebutkan bahwa asas utama dari Quantum Teachingadalah: Bawalah Dunia Mereka ke Dunia Kita, dan Antarkan Dunia Kita ke Dunia Mereka.Siapapun yang belajar sejalan dengan asas tersebut tentu akan tidak jauh berbeda responnya, temasuk siswa kelas 3.1 dan 3.2 SD Negeri Kleco 1 No.7 Surakarta tahun pelajaran 2013/2014.Kedua strategi pembelajaran yang diterapkan di kelas 3.1 dan 3.2 juga memiliki persamaan, yaitu menggunakan cooperative learning.

Strategi pembelajaran Cartoon Cardmenyajikan pembelajaran dengan suasana belajar bersama tokoh kartun idola siswa. Kartun merupakan tokoh yang sangat diminati siswa saat ini. Suasana belajar yang menyenangkan bersama kartun idola membuat siswa senang dan nyaman dalam proses belajar, karena mereka belajar dengan hal yang mereka sukai. Seperti yang dikemukakan Hagane,Ginga: 2011 dalam website (wiki.answers.com) menyebutkan bahwa " $89 \%$ of children watch cartoons while $11 \%$ of children do not watch cartoons". Jadi, pemanfaatan kartun dapat mengubah suasana pembelajaran lebih menarik, menyenangkan dan memotivasi siswa untuk lebih semangat dalam proses pembelajaran.

Anak usia kelas 3 SD yaitu berkisar 8 9 tahun kegiatan dalam kesehariannya masih didominasi dengan kegiatan bermain yang menampilkan anak selalu terlihat ceria, bersemangat, dan merasa senang (Jonny,
2009:1). Srategi pembelajaran Course Review Horay merupakan strategi yang menyajikan kekompakan dan keceriaan dalam pembelajarannya. Siswa bersama kelompoknya yang mendapatkan jawaban benar membentuk garis lurus dapat mengatakan "horay" atau menyanyikan yelyel kelompoknya. Kompetisi yang terjalin dalam penerapan strategi Course Review Horay sesuai dengan karakteristik siswa sekolah dasar yang mulai mampu berkompetisi dengan teman sebaya(Saring, dkk, 2008: 48-54).

Perbedaan skor rata-rata antara kedua strategi yang tidak signifikan, membuktikan bahwa strategi pebelajaran Cartoon Card tidak lebih besar pengaruhnya atau setara dengan strategi pembelajaran Course Review Horay terhadap motivasi belajar Matematika pada siswa kelas 3 SD Negeri Kleco 1 No.7 Surakarta tahun pelajaran 2013/1014. Kesetaraan antara strategi pembelajaran Cartoon Card dan Course Reiew Horay, selain karena alasan di atas juga dikarenakan penerapan strategi pembelajaran di kelas yang berbeda dan subjek yang berbeda pula, sehingga mempengaruhi hasil yang dicapai. Penerapan strategi pembelajaran yang berbeda terhadap siswa yang berbeda, memungkinkan siswa membandingkan pembelajaran sebelum dengan sesudah diberikan perlakuan, sehingga hasil yang diperoleh tidak sesuai dengan hipotesis kedua yang diharapkan dalam penelitian ini.

\section{SIMPULAN}

Berdasarkan analisis data yang dilakukan dapat diambil kesimpulan: (1) Tidak terdapat perbedaan motivasi belajar Matematika antara penerapan strategi pembelajaran Cartoon Card dengan strategi pembelajaran Course Review Horaypada siswa kelas 3 SD Negeri Kleco 1 No.7 Surakarta tahun pelajaran 2013/2014. Itu dapat dilihat dari $\mathrm{t}_{\text {hitung }}<\mathrm{t}_{\text {tabel }}$, yaitu $0,78<$ 2,301 dan nilai probabilitas $0,938>0,05$. (2) Strategi pembelajaran Cartoon Card tidak lebih besar pengaruhnya atau setara dengan strategi pembelajaran Course Review Horay Copyright $\odot 2018$, JRPD, ISSN 2615 - 1723 (Print), ISSN 2615 - 1766 (Online) 
terhadap motivasi belajar Matematika pada siswa kelas 3 SD Negeri Kleco 1 No.7 Surakarta tahun pelajaran 2013/2014. Hal tersebut dibuktikan dengan skor rata-rata motivasi belajar Matematika kelas 3.1 yang tidak berbeda secara signifikan dengan kelas 3.2 , yaitu adalah $91,80-91,60=0,20$.

\section{DAFTAR PUSTAKA}

DePorter, Bobbi, dkk. 2000. Quantum Teaching: Mempraktikkan Quantum Learning di Ruang-Ruang Kelas. Bandung: Kaifa.

Faisal, dkk. 2013. Model Pembelajaran Kontekstual Berbasis Cartoon Art(online), (http:// mpcartoonart.blogspot.com/2013/07/m odel - pembelajaran - kontekstualberbasis.html, diakses pada tanggal 26 Januari 2014).

Galuh E.P. 2012. "Studi Komparasi Hasil Belajar Matematika Antara Pembelajaran Strategi Course Review Horay dengan Index Card Match pada Siswa Kelas IV SD Negeri Sambeng 1 Tahun Ajaran 2011/2012" (skripsi). Surakarta: FKIP Universitas Muhammadiyah Surakarta

Hagane, Ginga. 2011. What percent of children watch cartoon (online), (http://wiki.answers.com/Q/What_perc ent_of_children_watch_cartoon\&isLoo $\mathrm{kUp}=1$, diakses pada tanggal 4 Februari 2014)

Hasbullah. 2009. Dasar-dasar Ilmu Pendidikan. Jakarta: PT Raja Grafindo Persada

Heruman. 2007. Model Pembelajaran Matematika di Sekolah Dasar. Bandung: PT Remaja Rosdakarya

Jonny. 2009. Mengapa Anak Kecil Suka Bermain

(online),(http://id.answer.yahoo.com/qu estion/mengapa-anak-kecil-sukabermain.html, diakses pada tanggal 4 Februari 2014)
Saring, dkk. 2008. Perkembangan Peserta Didik.Surakarta: BP-FKIP UMS

Surtikanti \& Susanto, J. 2008. Strategi Belajar Mengajar. Surakarta: BP-FKIP UMS

Widiyanto, Joko. 2010. SPSS for Windows untuk Analisis Data Statistik dan Penelitian. Surakarta: BP-FKIP UMS 